\title{
Genetic and Molecular Analysis of Transgenic Rice cv. Rojolele Expressing Lactoferrin
}

\author{
Diah Rachmawati ${ }^{1}$, Budi Setiadi Daryono ${ }^{2}$, Tri Rini Nuringtyas ${ }^{3} \&$ Hiroyuki Anzai ${ }^{4}$ \\ ${ }^{1}$ Laboratory of Plant Physiology, Faculty of Biology, Universitas Gadjah Mada, Yogyakarta, Indonesia \\ ${ }^{2}$ Genetics Laboratory, Faculty of Biology, Universitas Gadjah Mada,, Yogyakarta, Indonesia \\ ${ }^{3}$ Laboratory of Biochemistry, Faculty of Biology, Universitas Gadjah Mada, Yogyakarta, Indonesia \\ ${ }^{4}$ Gene Research Center, Ibaraki University, 3-21-1 Chuo, Ami, Ibaraki, Japan \\ Correspondence: Diah Rachmawati, Laboratory of Plant Physiology, Faculty of Biology, Universitas Gadjah \\ Mada, Yogyakarta 55281, Indonesia. Tel: 62-274-580-839. E-mail: diahbudiharjo@gmail.com
}

\author{
Received: October 9, 2013 Accepted: November 15, 2013 Online Published: February 15, 2014 \\ doi:10.5539/jas.v6n3p1 URL: http://dx.doi.org/10.5539/jas.v6n3p1
}

\begin{abstract}
In a previous study, human lactoferrin gene have introduced into Javanica rice cv. Rojolele by Agrobacterium-mediated transformation. Lactoferrin (LF) is an $80 \mathrm{kDa}$ iron-binding glycoprotein that has been proposed to have many biological roles such as protection against microbial and virus infection. This study aims to analyze the integration and level of lactoferrin gene expression of transgenic rice cv. Rojolele. The study also aims to examine the genetic character of transgenic rice expressing recombinant lactoferrin. Stability expression of recombinant lactoferrin transgenic rice seeds over generations were analyzed by ELISA, while the integration stability of recombinant hLF gene in transgenic plants performed by PCR. The mitotic time, cell cycle and chromosome characterization of transgenic and non-transgenic rice cv. Rojolele were determined. Chromosome characterization of the trangenic and non transgenic rice cv. Rojolele was investigated to determine the genetic variation. All of the above efforts were aimed to evaluate the genetically engineered rice containing recombinant lactoferrin as a nutraceutical food. The results showed that the expression was stable through three consecutive generations. The expression of the $h L F$ gene increased during grain-filling period. The active time of mitotic cells of transgenic rice rojolele was longer than the cells of non-transgenic rice. In addition, the cycle cell of transgenic and non-transgenic rojolele contained prophase, prometaphase, metaphase, anaphase, telophase and interphase. The result showed that all of the transgenic lines had diploid $(2 n)$ chromosome number $=24$.
\end{abstract}

Keywords: lactoferrin, transgenic rice cv. rojolele, karyotype, mitotic time

\section{Introduction}

Rice is one of the very few major food sources of the world. Rojolele is a famous of Javanica rice cultivar that is cultivated commercially in Indonesia. Rojolele has become a popular local rice variety in Central Java and is distributed throughout Indonesia because it has an aromatic fragrance and a delicious taste (Mudjisihono et al., 2002). Rachmawati et al. (2005) have been introduced the lactoferrin gene into Javanica rice cv. Rojolele. The transgenic plants expressed recombinant lactoferrin in the grain. Further studies are needed to determine the usefulness of engineered rice as a nutraceutical food.

Human milk proteins are considered to play many biological activities that are beneficial to the newborn infants, such as protection against infection. Lactoferrin (LF) is an $80-\mathrm{kDa}$ iron-binding glycoprotein present of high concentrations (average 1-2 g/l) in human milk (Nandi et al., 2002). It is a bioactive milk protein playing an important role in the immune system response and contributing to the protection of the body against infections (Brock et al., 2000). In addition to the stimulation of the immune system, scientific studies have revealed that lactoferrin also prevents the growth of pathogens, exhibits antibacterial and antiviral properties, controls cell and tissue damage caused by oxidation, and facilitates iron transport (Lönnerdal, 2000; Tomita et al., 2000; Brock, 2002). Moreover, it has been reported that lactoferrin is a protein contributing to the growth promotion of Bifidobacteria (Kim et al., 2004). 
We have expressed the human lactoferrin protein (hLF) in rice cultivar Rojolele under the control of the promoter ubiquitin. This protein was genetically fused to the signal peptide from rice glutelin. The expression levels of rhLF significantly increased in the mature seeds. A considerable amount of recombinant hLF (rhLF) in seeds were approximately $15 \%$ of the total soluble protein (Rachmawati et al., 2005). However, protein expression level depends on both production and stability. The factors that control high-level accumulation of recombinant proteins in seed include promoters and enhancers, subcellular trafficking and targeting of the desired polypeptides or proteins (Boothe et al., 2010). Subcellular targeting plays an important role in determining the yield of recombinant proteins because the compartment where a protein accumulates can strongly influence the interrelated processes of folding, assembly, and post-translational modification (Fischer et al., 2004). Many factors contribute to variation in transgene expression, including the position of transgene integration, copy number of transgene and configuration of transgenic locus, as well as mechanisms of epigenetic silencing (Iglesias et al., 1997; Fagard \& Vaucheret, 2000; Ma et al., 2003). When transgene integrate into genomic DNA, the expression level is often influenced by the surrounding chromatin (Gelvin, 2003). Transgene copy number can greatly affect the expression level and genetic stability of the target gene (Donnarumma et al., 2011).

In contrast to the rapid progress of molecular analysis of the rice genome, only limited success has been achieved toward a cytogenetic characterization of the rice genome. Karyotypes of japonica and indica rice has been reported by Kurata and Omura (1978), while javanica rice has not been reported yet.

The aim of this study was to analyze the stability of recombinant human lactoferrin expressed in rice seeds. The study also aims to examine genetic character of transgenic rice expressing recombinant lactoferrin. All of the above efforts aimed to evaluate the genetically engineered rice containing recombinant lactoferrin as a nutraceutical food.

\section{Methods}

\subsection{Plant Materials}

Javanica rice cv. Rojolele was obtained from Yogyakarta Assessment Institute for Agricultural Technology (DIY AIAT), Indonesia. Transgenic rice cv. Rojolele expressing recombinant human lactoferrin gene was obtained through Agrobacterium-mediated transformation (Rachmawati et al., 2005). Transgenic lines TR-7, TR-8, and TR-10 carried mature human lactoferrin gene was fused to the DNA sequence encoding the rice glutelin signal peptide with the constitutive maize ubiquitin-1 promoter. The transgenic lines TR-7, TR-8, and TR-10 contained 2,1 and 3 copies of hLF gene. Transgenic and non transgenic were analyzed for cell cycle and karyotype, stability of expression and integration of recombinant human lactoferrin.

\subsection{Expression of Recombinant Human Lactoferrin (rhLF)}

The expression levels of rhLF in the transgenic plants were quantified by sandwich ELISA. A 96-well microtiter plate (Nunc-Immunoplate C96 Maxisorp, Denmark) was coated with $100 \mu \mathrm{l}$ of rabbit anti-hLF $(1 \mu \mathrm{g} / \mathrm{ml})$ in PBS $\left(8.1 \mathrm{mM} \mathrm{Na} 2 \mathrm{HPO}_{4}, 1.5 \mathrm{mM} \mathrm{KH}_{2} \mathrm{PO}_{4}, 2.7 \mathrm{mM} \mathrm{KCl}, 137 \mathrm{mM} \mathrm{NaCl}\right)$ at $4{ }^{\circ} \mathrm{C}$ overnight. After the plate was equilibrated at room temperature for $1 \mathrm{~h}$, the coating solution was removed and the plate was washed with PBS-T [PBS containing $0.05 \%(\mathrm{v} / \mathrm{v})$ Tween-20]. Then $200 \mu \mathrm{l}$ of blocking solution [1\% (w/v) non-fat dry milk (Nacalai Tesque), $0.1 \%$ Tween-20, $0.05 \%$ (w/v) Merthiolate (SIGMA) in PBS] was added to the well. The plate was incubated at $4{ }^{\circ} \mathrm{C}$ overnight and washed three times with PBS-T. Protein samples (100 $\mu$ l) at an appropriate dilution and standard LF were prepared in the blocking solution and then added to the wells. The plate was incubated at $37^{\circ} \mathrm{C}$ for $1 \mathrm{~h}$ and washed with PBS-T. Immunodetection was performed at $37^{\circ} \mathrm{C}$ using rabbit anti-hLF antibody (Fab') and goat anti-rabbit IgG coupled to HRP at 1:1000 dilutions in PBS-T. One hundred microliters of the diluted HRP-conjugated secondary antibody were added into each well and the plate was incubated at $37^{\circ} \mathrm{C}$ for $1 \mathrm{~h}$. After three times washing with PBS-T, staining was initiated by adding $100 \mu \mathrm{l}$ of substrate orthophenyldiamine dichloride in $0.05 \mathrm{M}$ Phosphate-Citrate buffer and the plate was incubated at room temperature for $10 \mathrm{~min}$. The reactions were stopped with $100 \mu \mathrm{l}$ of $1 \mathrm{M} \mathrm{H}_{2} \mathrm{SO}_{4}$ per well. The plates were read at $490 \mathrm{~nm}$. Raw ELISA data were converted to nanogram/milliliter of rhLF of total soluble protein by reference to an ELISA standard curve constructed using native hLF. The rhLF expression over generations were statistically analyzed using $\mathrm{T}$ test at significancy level of $95 \%$.

\subsection{Integration and Segregation of hLF Gene}

Integration of the hLF gene under the control of a constitutive promoter over generations was performed by PCR analysis. Genomic DNA was isolated from mature leaves according to the method of Murray and Thomson (1980). Briefly, one gram of fresh leaf tissue was homogenized to a powder in liquid nitrogen by a mortar and a 
pestle. The tissue powder obtained was suspended in $5 \mathrm{ml} \mathrm{CTAB}$ extraction buffer [ $2 \% \mathrm{CTAB}, 1.4 \mathrm{M} \mathrm{NaCl}, 20$ $\mathrm{mM}$ EDTA, $0.1 \mathrm{M}$ Tris- $\mathrm{HCl}(\mathrm{pH} 8.0), 0.2 \%$ 2-mercaptoethanol] and incubated at $60^{\circ} \mathrm{C}$ for $30 \mathrm{~min}$. The suspension was then purified by phenol:chloroform:isoamylalcohol $(25: 24: 1)$ extraction and precipitated by 2-propanol. The DNA was dissolved in TE buffer [10 mM Tris-HCl (8.0), 1 mM EDTA].

PCR analysis was carried out in a $20 \mu \mathrm{l}$ reaction mixture containing $200 \mu \mathrm{M}$ of dNTPs $(1 \mu \mathrm{l}), 0.5 \mu \mathrm{M}$ of each primer $(1 \mu \mathrm{l}), 0.02$ unit Taq DNA Polymerase $(0.2 \mu \mathrm{L})$ (Takara Bio Inc), $1 \mathrm{x}$ Taq Buffer $(2 \mu \mathrm{l})$, genome DNA $(1$ $\mu \mathrm{l})$, and $\mathrm{ddH}_{2} \mathrm{O}(15.8 \mu \mathrm{L})$. The amplification reaction was 1 cycle of $95^{\circ} \mathrm{C}$ for 2 min followed by 30 cycles of $95^{\circ} \mathrm{C}$ for $1 \mathrm{~min}, 54^{\circ} \mathrm{C}$ for $2 \mathrm{~min}$ and $72^{\circ} \mathrm{C}$ for $3 \mathrm{~min}$, and one cycle of $8 \mathrm{~min}$ at $72^{\circ} \mathrm{C}$. This reaction was carried out in an eppendorf Mastercycler personal. Primers used for amplification of the hLF gene were LF8: 5'-TCACTGCCATCCAGAACTTG and LF9: 5'-TCTGATCTCCTAACCACCGC. The primers amplified an internal hLF sequence of $356 \mathrm{bp}$. The amplification products from transgenic and non-transgenic plants were separated on a $1.5 \%$ agarose gel and visualized by UV fluorescence of the ethidium bromide-stained DNA. Segregation of hLF gene on transgenic rice was determined based on PCR analysis followed by chi-square test.

\subsection{Expression of rhLF During Rice Endosperm Developments}

Expression of rhLF during endosperm development of the rice was monitored at 7, 14, 21, 28, 35, and 42 DAP (Day After Pollination). Immature spikelets were harvested at 7, 14, 21, 28, 35, and 42 DAP (Day After Pollination) and analyzed for the rhLF expression by ELISA. Expression of rhLF in transgenic rice during endosperm development was confirmed by SDS-PAGE and Western blot analysis .

The extracted proteins from transgenic rice seeds $(5 \mu \mathrm{g})$ were treated with sample buffer [ $60 \mathrm{mM}$ Tris- $\mathrm{HCl}(\mathrm{pH}$ $6.8), 10 \%(\mathrm{w} / \mathrm{v})$ glycerol, $2 \%(\mathrm{w} / \mathrm{v})$ SDS, and $0.01 \%$ bromophenol blue with $5 \%(\mathrm{v} / \mathrm{v}) 2$-mercaptoethanol] and were boiled for $5 \mathrm{~min}$ at $99^{\circ} \mathrm{C}$. SDS-PAGE was performed according to the method of Laemmli (1970) using a $10 \%$ polyacrylamide gel. Electrophoresis was performed in $25 \mathrm{mM}$ Tris, $192 \mathrm{mM}$ glycine, $0.1 \%(\mathrm{w} / \mathrm{v})$ SDS buffer at $20 \mathrm{~mA}$ for $30 \mathrm{~min}$. The proteins in the gel were stained with Coomassie Brilliant Blue (Rapid Stain CBB Kit, Nacalai Tesque). For western blot analysis, the separated proteins in the polyacrylamide gel were transferred to transfer buffer [12.5 mM Tris- $\mathrm{HCl}(\mathrm{pH} 8.8), 86 \mathrm{mM}$ glycine, $10 \% \mathrm{MetOH}]$ and transblotted onto a $0.45 \mu \mathrm{m}$ PVDF membrane (Nihon Eido, Japan) using a semidry-blotting apparatus (Nihon Eido, Japan) for 1 hour at $140 \mathrm{~mA} /$ gel. The blot was blocked with $5 \%(\mathrm{w} / \mathrm{w})$ skimmed milk in PBS-T $\left(8.1 \mathrm{mM} \mathrm{Na}_{2} \mathrm{HPO}_{4}, 1.5 \mathrm{mM}\right.$ $\mathrm{KH}_{2} \mathrm{PO}_{4}, 2.7 \mathrm{mM} \mathrm{KCl}, 137 \mathrm{mM} \mathrm{NaCl}, 0.01 \%$ Tween-20) for $1 \mathrm{~h}$ followed by three washes with PBS-T for 10 min each times. PBS-T solution containing 5\% skimmed milk was used to block nonspecific binding of primary antibody. The blot was incubated in the primary antibody [rabbit anti-hLF antiserum was diluted at 1:1000 in PBS-T] for $1 \mathrm{~h}$ followed by three washes in PBS-T. The blot was incubated in the secondary antibody solutions [goat anti-rabbit IgG HRP-conjugate (BIORAD) was diluted in PBS-T at a 1:1000 in PBS-T] for $1 \mathrm{~h}$ at room temperature. After three washes, the blot was stained with HRP staining solution using Konika immunostaining HRP1000 until the signal of the positive control was clearly visible. The staining was stopped by distilled water.

\subsection{Studies on Cell Cycle and Karyotype of Transgenic and Non Transgenic Rice}

Chromosomes were prepared according to the methods described by Jashier and Tanguy (1996). Seeds of transgenic and non transgenic rice were sown and germinated in petridish. The root were cut about 3-5 $\mathrm{mm}$ and used as sample for chromosome preparation. Chromosome preparation was conducted from 08.00 a.m. to 10.00 a.m. with 15 minute intervals. Fresh root tips of germinated seeds were fixed in $45 \%$ acetic acid at $4{ }^{\circ} \mathrm{C}$ for 15 minutes. Fixed root tips were then macerated in $1 \mathrm{~N}$ hydrochloric acid for about 11 minutes at $55^{\circ} \mathrm{C}$. The root tips were stained in $1 \%$ aceto-orcein for about 24 hours before they squashed. The slides were then photographed using Olympus C-35-AD-4 and Fuji film ASA 200.

Characterization of chromosomes and karyotype formulation based on the number of chromosomes, length of the short arm (p) and long arm (q), the absolute length of chromosomes $(p+q)$ and centromere index. The centromere index was calculated using the following formula: Centromere Index = (length of the long arm/ the absolute length of chromosomes) x 100 .

The measurement of chromosome size was made on the chromosomes observed at prometaphase using Adobe Photoshop CS2 for Windows program. Centromere position of chromosome was classified by centromeric index calculated by short arm/ total length following Levan et al. (1964). Metacentric chromosome with centromeric index of 37.50-50.00; submetacentric chromosome with centromeric index of 25.00-37.49; subtelocentric chromosome with centromeric index of 12.5-24.99; and telocentric chromosome with centromeric index of 0-12.49. Data of chromosome size and centromere position of chromosomes were then arranged to construct karyogram using Adobe Photoshop CS2 for Windows program, and idiogram using CorelDRAW Graphic Suite 
X3. Characterization of the genetic trait of transgenic and non transgenic rice including chromosome number, mitotic time, cell cycle and karyotype.

\section{Results}

\subsection{Expression of Recombinant Human Lactoferrin}

In this study, the T2 and T3 seeds of transgenic rice expressed recombinant human lactoferrin were analyzed to determine their stability. The stability of the rhLF expression under the control of a constitutive promoter of the three transgenic lines TR-7, TR-8 and TR-10 were examined using ELISA. The rhLF expression levels in the T1 seeds varied among transgenic lines, such as TR-7, TR-8 and TR-10 were $1.6 \mathrm{mg} / \mathrm{g}$ DW of dehusked seeds, 2.0 $\mathrm{mg} / \mathrm{g}$ DW of dehusked seeds and $1.0 \mathrm{mg} / \mathrm{g}$ DW of dehusked seeds. The rhLF expression levels in the T1 seeds were almost identical with those in the T2 seeds as well as T3 seeds for the same transgenic lines (Figure 1). The results indicated that recombinant lactoferrin in mature seeds was stable through three consecutive generations.

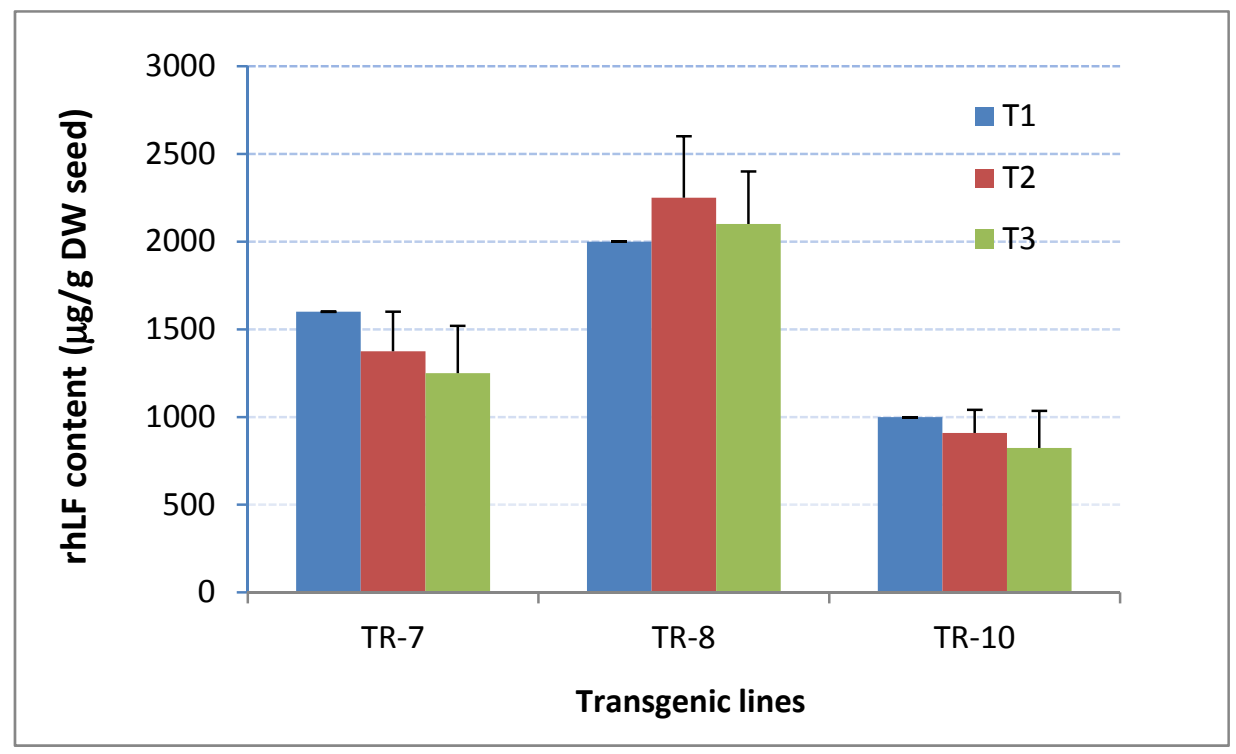

Figure 1. Expression levels of rhLF in $\mathrm{T}_{1}, \mathrm{~T}_{2}$ and $\mathrm{T}_{3}$ seeds

\subsection{Integration and Segregation of hLF Gene}

Segregation of hLF on transgenic rice was determined based on PCR analysis followed by chi-square test (Table 1). From the calculation of chi-square test on transgenic lines TR-7 and TR- 8 showed the value of $\chi 2=1.333$ and 2.557. From table $\chi 2$ with degrees of freedom 1 , the P-value lies between 0.1 and 0.3 . Because P-values are higher than 0.05 , therefore data meet the 3:1 ratio and can be said that the segregation of these transgenic lines followed the Mendelian patterns. Meanwhile, for TR-10 showed the 15:1 ratio with the $\chi 2=0.938$. Based on the table $\chi 2$ with degrees of freedom 1 , the P-value lies between 0.3 and 0.5 and can be said that segregation of transgenic line TR-10 also followed the Mendelian patterns.

Table 1. Segregation of hLF gene in seeds of transgenic rice Rojolele in $3^{\text {rd }}$ generation

\begin{tabular}{ccccc}
\hline Transgenic line & \multicolumn{2}{c}{$h L F$ copy number } & \multicolumn{3}{c}{ Number of seeds analyzed } & $\chi 2$ \\
& in $\mathrm{T}_{0}$ generation $^{1)}$ & Total & LF $^{+}$ & \\
\hline TR-7 & 2 & 100 & 80 & 1.333 \\
TR-8 & 1 & 95 & 78 & 2.557 \\
TR-10 & 3 & 92 & 84 & 0.938
\end{tabular}

1) The copy number in the $\mathrm{T}_{0}$ generation was determined by Southern blot analysis with a $h L F$ probe.

(Rachmawati et al., 2005). 


\subsection{Expression of rhLF During Rice Endosperm Developments}

The rhLF expression during endosperm development of the rice transgenic lines were monitored in TR-7. Immature spikelets were harvested at 7, 14, 21, 28, 35, and 42 DAP (Day After Pollination) and analyzed for the rhLF expression by ELISA. The rhLF expression in seed of transgenic lines TR-7 were detected at 7 DAP (still in milky stage) and dramatically increased at 21 DAP, thereafter the rhLF content slightly increased through seed maturation (Figure 2A). These results were consistent as reported by Bechtel and Juliano (1980) that protein body deposition begins about 7 days after pollination and gradually increased during rice endosperm development. Based on SDS-PAGE and western blot analysis (Figures 2B-C), high level of rhLF was detected on mature seeds of transgenic rice cv. Rojolele.

$\mathbf{A}$

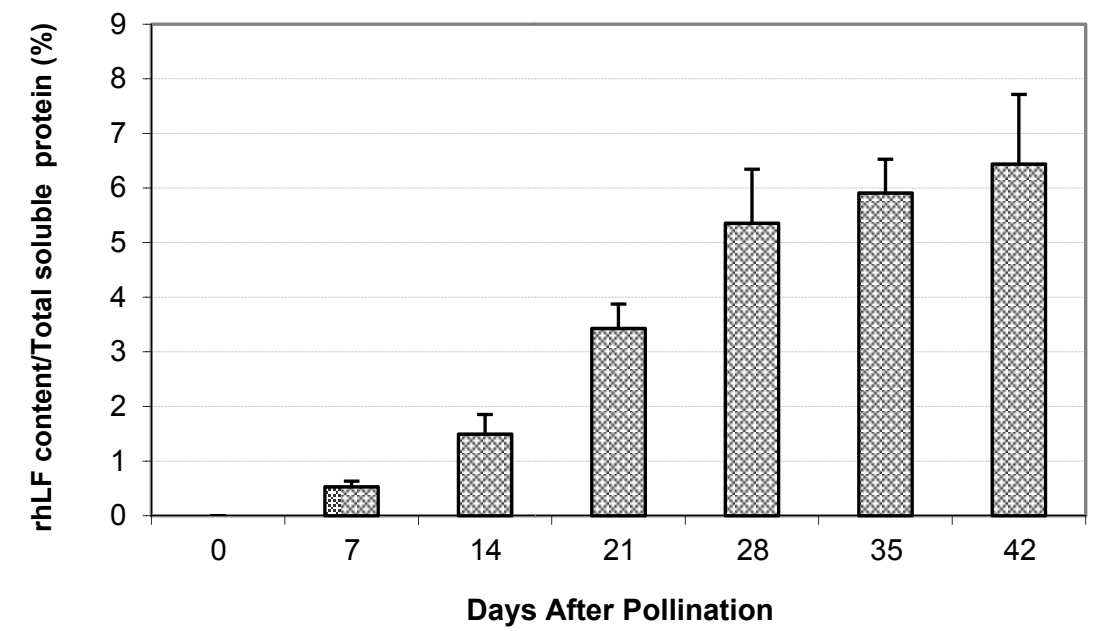

B

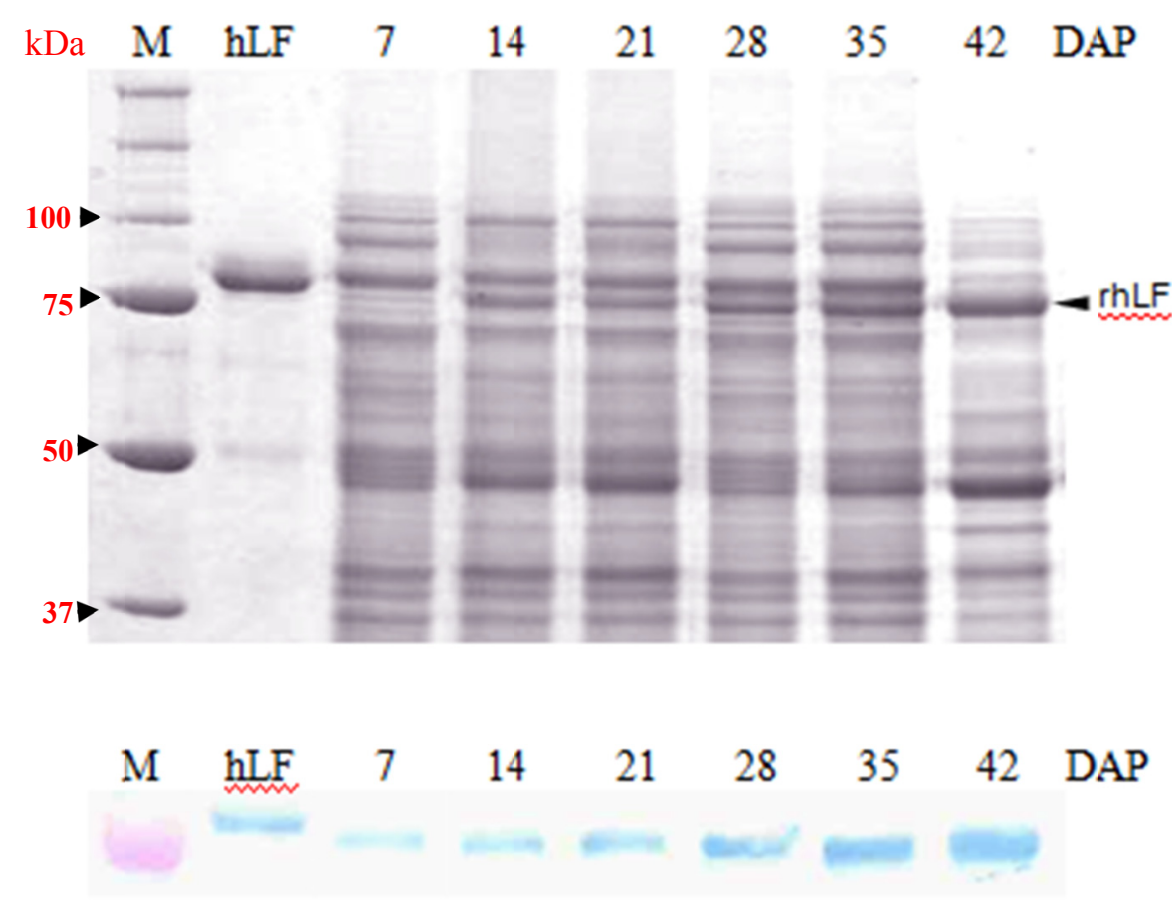

Figure 2. Expression of rhLF during rice endosperm developments. Immature spikelets at 7, 14, 21, 28, 35, and 42 DAP (Day After Pollination) were analyzed for rhLF expression by ELISA (A), SDS-PAGE staining with

CBB (B) and Western blot analysis (C) 
As shown in figure 2B-C, SDS-PAGE staining with $\mathrm{CBB}$ and western blot analysis demonstrated that the molecular weight of rhLF in transgenic rice was slightly smaller than that of native hLF. Based on MALDI-TOF Mass spectrometry analysis the molecular weight of rhLF was $77801 \mathrm{Da}$, while the molecular weight of native hLF was 79827 Da.

\subsection{Studies on Cell Cycle and Karyotipe of Transgenic and Non Transgenic Rice}

In this research, transgenic rice expressing recombinant human lactoferrin were used as material. Studies of the cell cycle obtained active time of mitotic cells in transgenic rice cv. Rojolele TR-7, TR-8 and TR-10 were longer than the cells of non-transgenic rice. At that time there were many cells in a state prometaphase. In prometaphase, the chromosomes are in the form of the most solid and well dispersed, therefore easy to observe.

Based on observation, the number of chromosomes of rojolele transgenic rice and non-transgenic are $2 \mathrm{n}=24$ (Figures 3A, 3B, 3C and 3D). Three lines of transgenic rice investigated in this study had similar chromosome number $(2 n=24)$ to the non-transgenic rice. This amount is in accordance with the research on the rice chromosome number of Cianjur $2 n=24$ (Daryono \& Sumardi, 1996). The findings of the research are expected to enrich valuable information concerning the genetic identity and diversity of rice.

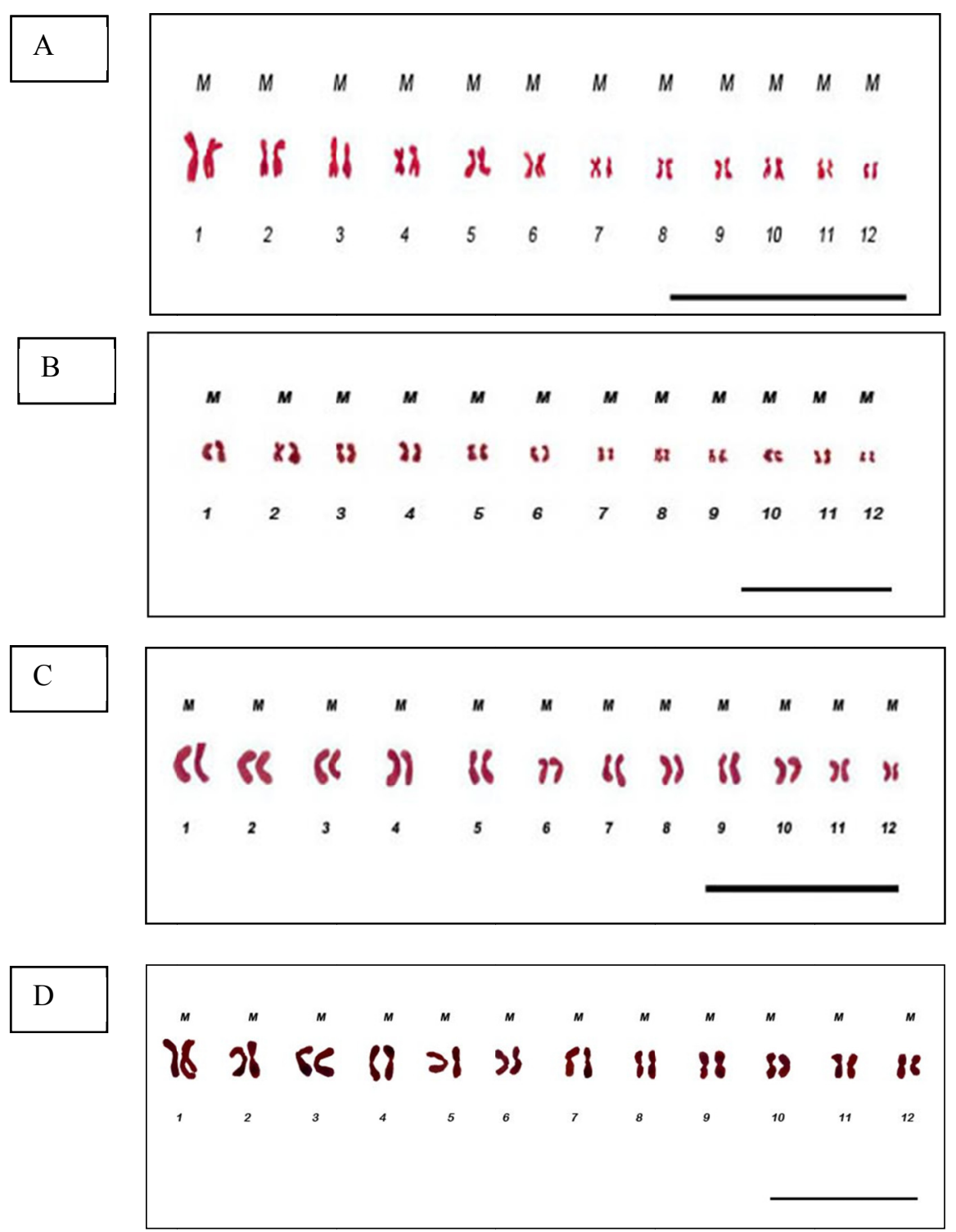

Figure 3. Karyotype of transgenic rice expressing recombinant lactorferrin. A: non-transgenic B:TR-7, C:TR-8, and D:TR-10. Scale bar correspond to $0,5 \mu \mathrm{m}$. $(\mathrm{m}=$ metacentric chromosome; number under the karyotype correspond to chromosome pairs) 
From the result showed in Figure 3, we can note that there is only one group karyotipe symmetry group (metacentric). According to Singh (1999), karyotipe symmetry is considered more conservative when compared with karyotipe asymmetry in its evolution. Thus, it is known that rice cultivars of Rojolele that have chromosomal symmetry shows the evolution of a more conservative level or Rojolele rive cultivar has not been crossed with another rice cultivar.

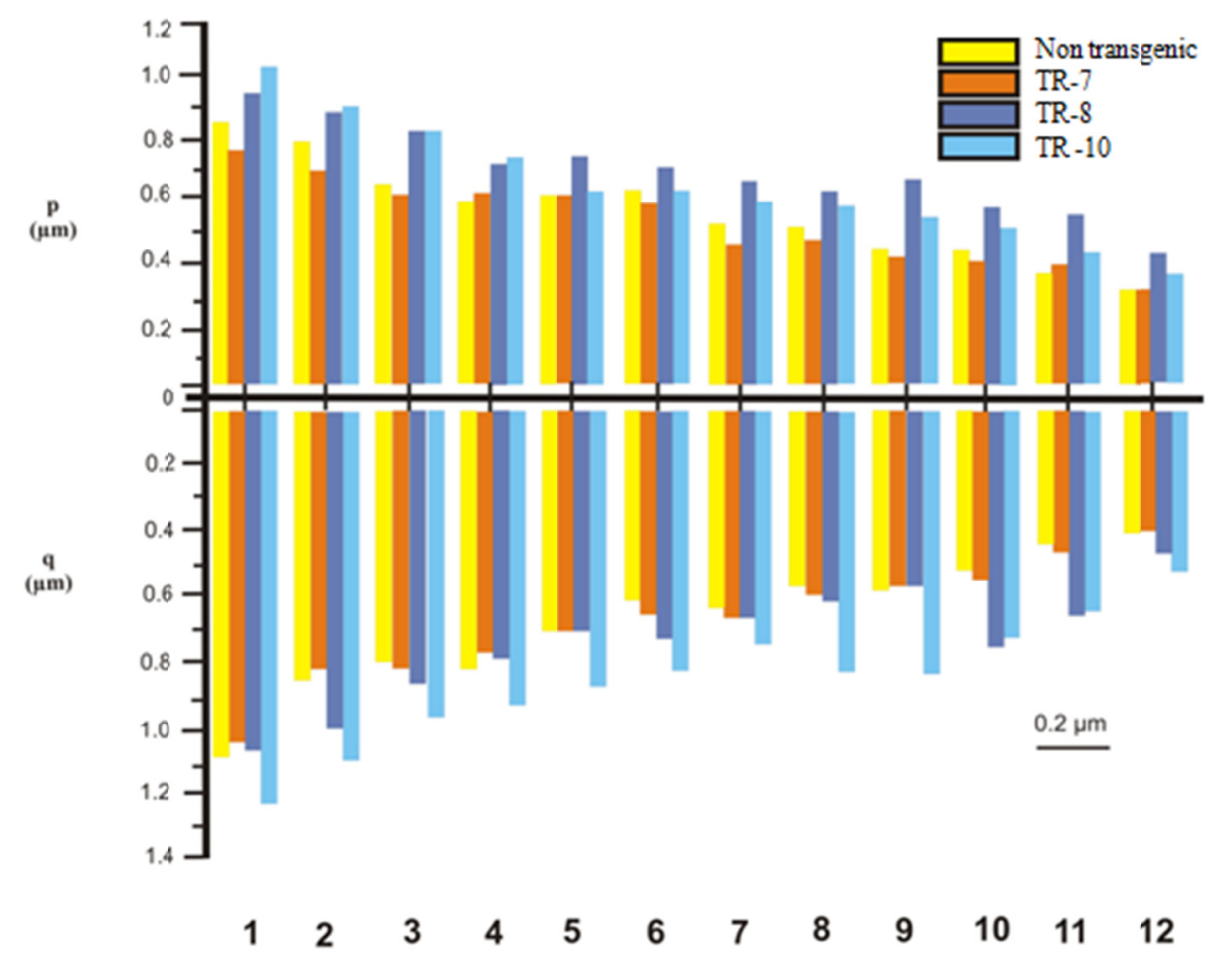

Figure 4. Idiogram showing comparison chromosome size among non-transgenic and transgenic rice expressing recombinant lactoferrin TR-7, TR-8 and TR-10. Number below the figure showed chromosome pairs. Scale bar correspond to $0.2 \mu \mathrm{m}$

The diploid chromosome number of Oryza sativa L. cv. Rojolele was $2 \mathrm{n}=24$ consisted 12 pairs of metacentric chromosomes displaying karyotype formula $2 \mathrm{n}=2 \mathrm{x}=24 \mathrm{~m}$ (Figure 3 and Table 2). Eventhough karyotype formula of transgenic was similar to non transgenic rice, there were differences in chromosome size (Table 2). The $\mathrm{R}$ value showed proportion of largest chromosomes total length with the smallest chromosome total length. The $\mathrm{R}$ results of transgenic lines TR-7, TR-8, TR-10 and non transgenic were 2.841, 2.421, 3.174 and 2.743 respectively. The findings of the research are expected to enrich valuable information concerning the genetic identity of transgenic rice expressing recombinant human lactoferrin gene.

Table 2. Chromosome length, karyotype and $\mathrm{R}$ value of non-transgenic and transgenic rice TR-7, TR-8 and TR-10

\begin{tabular}{lcccc}
\hline \multicolumn{1}{c}{ Characters } & Non-transgenic Rojolele & Transgenic TR-7 & Transgenic TR-8 & Transgenic TR-10 \\
\hline Short arm (p) & $0.314-0.969 \mu \mathrm{m}$ & $0.318-0.783 \mu \mathrm{m}$ & $0.437-0.969 \mu \mathrm{m}$ & $0.355-1.132 \mu \mathrm{m}$ \\
Long arm (q) & $0.402-1.090 \mu \mathrm{m}$ & $0.414-1.071 \mu \mathrm{m}$ & $0.585-1.056 \mu \mathrm{m}$ & $0.465-1.253 \mu \mathrm{m}$ \\
Total length (p+q) & $0.717-1.967 \mu \mathrm{m}$ & $0.732-1.456 \mu \mathrm{m}$ & $1.021-2.024 \mu \mathrm{m}$ & $0.820-2.384 \mu \mathrm{m}$ \\
Karyotipe & $2 \mathrm{n}=2 \mathrm{x}=24=24 \mathrm{~m}$ & $2 \mathrm{n}=2 \mathrm{x}=24=24 \mathrm{~m}$ & $2 \mathrm{n}=2 \mathrm{x}=24=24 \mathrm{~m}$ & $2 \mathrm{n}=2 \mathrm{x}=24=24 \mathrm{~m}$ \\
R value & 2.743 & 2.841 & 2.421 & 3.174 \\
\hline
\end{tabular}


Three lines of transgenic rice expressing rhLF investigated in this study had chromosome number $(2 n=24)$. This count was similar from the previous studies reported by Kurata et al. (1981), who recorded that the diploid chromosome number of indica or japonica rice. Therefore, it can be concluded that insertion of hLF in Rojolele rice did not change the chromosome number and their karyotipe.

\section{Discussion}

We have analyzed the stability expression of recombinant human lactoferrin transgenic rice seeds over generations. Transgenic rice expressing hLF with the signal peptide from rice glutelin under the control of the maize ubiquitin-1 promoter were obtained by Agrobacterium-mediated transformation. This promoter has been shown to be constitutive in rice, conferring high-level transgene expression in the endosperm of seeds.

Recombinant human lactoferrin expression under the control of the constitutive maize ubiquitin-1 promoter significantly increased in the seeds, but not in the vegetative tissues of the transgenic plants. The rhLF was produced in rice seeds at levels exceeding $15 \%$ of the total soluble protein. In the vegetative tissues of transgenic plants, these proteins are expressed at low levels, typically less than $0.8 \%$ of the total soluble protein (Rachmawati et al., 2005). Huang (2004) reported the expression level of human lysozyme under the control of storage protein promoters has resulted in an average expression level of $13 \%-14 \%$ of total soluble protein. Werner at al. (2011) also reported the expression of recombinant protein expression (GFP) at at different tissues in transgenic Nicotiana benthamiana. No fluorescence could be detected in the stem, whereas leaf and stem tissue of an induced plant gave approximately the same relative expression levels.

We found that the highest level of rhLF expression with the rice glutelin signal peptide was $2.0 \mathrm{mg} / \mathrm{g}$ dry weight of dehusked seeds (TR-8). The stability of the hLF gene expression under the control of a constitutive promoter over generations, we carried out further analysis of three transgenic lines i.e. TR-7, TR-8 and TR-10. These lines were chosen based on ELISA results showing high expression levels of rhLF. The rhLF expression level varied among independent transgenic lines. The expression level of rhLF in transgenic line TR-8 was higher that in transgenic line TR-7 and TR-10. Based on southern blot analysis, transgenic lines TR-8 contained one copy of hLF gene while TR-7 and TR-10 contained 2 and 3 copies. As reported by Ma et al. (2003), the expression level of recombinant protein depends on various factors, including the gene expression construct, the position of transgene integration, the structure of the transgenic locus, copy number of transgene, and the presence of truncated or rearranged transgene copies. Transgene copy number can greatly affect the expression level and genetic stability of the target gene (Donnarumma et al., 2011). Multiple gene copies might suppress the expression of foreign gen in transgenic plants, therefore important to screen transformants with single transgene copy to avoid repeat-induced silenced ( $\mathrm{Li} \mathrm{Xu}$-Gang et al., 2002). The rhLF expression levels in the T1 seeds were almost identical with those in the T3 seeds for the same transgenic line (Figure 1). The results indicated that recombinant lactoferrin in mature seeds was stable through three consecutive generations.

Recombinant hLF in transgenic rice showed a slightly smaller molecular weight than that of native hLF. We assumed that the size difference between rice rhLF and native hLF from human milk might be due to the modification of the sugar chain or glycosylation. Glycosylation systems in plants are different from those in mammals (Palacpac et al., 1999; Rayon et al., 1998; Spik \& Theisen, 2000). Plant-derived recombinant proteins tend to have carbohydrate groups $\beta(1,2)$-xylose and $\alpha(1,3)$-fucose, which are absent in mammals, but lack the terminal galactose and sialic acid residues found on many native human glycoproteins (Ma et al., 2003; Twyman et al., 2003). Spik and Theisen (2000) suggested that the difference in molecular weight between recombinant hLF and native hLF might be associated with the carbohydrate moiety, either the polypeptide chain or the glycan moiety. The difference in the protein size could be ascribed to the fact that the plant protein is not phosphorylated or is incompletely phosphorylated (Herman \& Larkins, 1999).

The results of cytological characterization exhibited that the time of mitotic cells of transgenic rice cv. Rojolele longer than that of non-transgenic, thus suspected to have influence lactoferrin gene insertion with respect to active time of mitosis. The finding of mitosis period of transgenic rice investigated in this study is useful to obtain prometaphase stages used to examine chromosome characters. Three lines of transgenic rice were investigated in this study had similar chromosome number $(2 n=24)$ to the non-transgenic rice. In addition all chromosome of transgenic rice and non transgenic rice also appeared to have the centromere in the median region and were thus classified as metacentric (Figure 3) and according to Levan et al. (1964) displaying similar karyotipe formula $(2 \mathrm{n}=2 \mathrm{x}=24=24 \mathrm{~m})$. The result showed that both transgenic and non-transgenic had chromosome metasentris (Figure 4). According to Singh (1999) plants that have a symmetrical karyotype (metasentris) is a primitive species. The finding of metacentric chromosomes in rojolele rice revealed that 
Rojolele investigated in this study have symmetry karyotypes indicating that Rojolele have not been cultivated for breeding program.

The diploid chromosome number of Oryza sativa L. cv. Rojolele was $2 \mathrm{n}=24$ consisted 12 pairs of metacentric chromosomes displaying karyotype formula $2 \mathrm{n}=2 \mathrm{x}=24 \mathrm{~m}$ (Figure 1 and Table 2). Eventhough karyotype formula of transgenic was similar to karyotype formula of non transgenic rice, there were differences in chromosome size. $\mathrm{R}$ value is comparison of the absolute length of the longest chromosome to the absolute length of the shortest chromosome. This value indicates the presence of chromosomal size variation. If a higher variation of chromosome size, then the $\mathrm{R}$ value obtained is also getting bigger. Based on the calculations shown in Table 2, the $\mathrm{R}$ values obtained for the non-transgenic rice Rojolele of 2.743 , while for transgenic Rojolele TR-7 = 2.841; TR- $8=2.182$ and TR-10 = 3.174. The difference between the R value of Rojolele non-transgenic rice and transgenic rice is 0.011 . This value showed that both transgenic and non transgenic rice Rojolele was the same parent of Oryza sativa L. cv. Rojolele. Therefore, the insertion of lactoferrin genes in Rojolele rice did not cause changes in chromosome size and their karyotipe. On the basis of the difference of $\mathrm{R}$ value, all types of transgenic rice have close genetic relationship and considered to be cultivated from same species or variety.

Expression of recombinant lactoferrin increased with seed ripening process. High expression of recombinant lactoferrin in mature seeds was stable through three consecutive generations. All types of transgenic rice had diploid chromosome number and karyotypes composed of 24 pairs of metacentric chromosomes. Formula karyotipe Rojolele rice cultivars is $2 \mathrm{n}=2 \mathrm{x}=24=24 \mathrm{~m}$.

\section{Acknowledgements}

We thanks to the Ministry of Research and Technology through Insentif Research Grant, 2007 for financial support, and we also would like to thank to Yulia Sari, Ani Widarti and Vitri for their laboratory works.

\section{References}

Bechtel, D. R., \& Juliano, B. O. (1980). Formation of protein bodies in the starchy endosperm of rice (Oryza sativa L.): a reinvestigation. Ann. Bot., 45, 503-509.

Boothe, J., Nykiforuk, C., Shen, Y., Zaplachinski, S., Szarka, S., Kuhlman, P., ... Moloney, M. M. (2010). Seed-based expression systems for plant molecular farming. Plant Biotechnology Journal., 8, 588-606. http://dx.doi.org/10.1111/j.1467-7652.2010.00511.

Brock, J. H. (2002) .The Physiology of lactoferrin. Biochem. Cell Biol, 80, 1-6. http://dx.doi.org/10.1139/o01-212

Brock, J. H., Guillen, C., \& Thompson, C. (2000). Anti-inflammatory and immunoregulatory properties of lactoferrin. In K. Shimazaki et al. (Eds), Proceedings of the 4th International Conference on Lactoferrin: Structure, Function and Applications (pp. 119-128). Elsevier Science B.V. The Netherlands.

Cheng, Z., Buell, C. R., Wing, R. A., Gu, M., \& Jiang, J. (2001). Toward a cytological characterization of the rice genome. Genome Res., 11, 2133-2141. http://dx.doi.org/10.1101/gr.194601

Daryono, B. S., \& Sumardi, I. (1996). The growth and ploidy levels of callus cells from rice anther culture (Oryza sativa L. cv. Cianjur) by 2,4-D treatment. Biology, 2(1), 11-18.

Donnarumma, F., Paffetti, D., Fladung, M., Biricolti, S., Dieter, E., Altosaar, I., \& Vettori, C. (2011). Transgene copy number estimation and analysis of gene expression levels in Populus spp. transgenic lines. BMC Proc., 5(Suppl 7), 152. http://dx.doi.org/10.1186/1753-6561-5-S7-P152

Fagard, M., \& Vaucheret, H. (2000). (Trans)gene silencing in plants: How many mechanisms? Annu. Rev. Plant Physiol. Plant Mol. Biol., 51, 223-256. http://dx.doi.org/10.1146/annurev.arplant.51.1.167

Fischer, R., Stoger, E., Schillberg, S., Christou, P., \& Twyman, R. M. (2004). Plant-based production of biopharmaceuticals. Curr Opin Plant Biol., 7(2), 152-8. http://dx.doi.org/10.1016/j.pbi.2004.01.007

Gelvin, S. B. (2003). Improving plant genetic engineering by manipulating the host. TRENDS in Biotech., 21, 95-98. http://dx.doi.org/10.1016/S0167-7799(03)00005-2

Herman, E. M., \& Larkins, B. A. (1999). Protein Storage Bodies and Vacuoles. The Plant Cell, 11, 601-613.

Huang, N. (2004). High-level protein expression system uses selfpollinating crops as hosts. BioProcess International., 2, 54-59. 
Iglesias, V. A., Moscone, E. A., Papp, I., Neuhuber, F., Michalowski, S., Phelan, T., ... Matzke, A. J. M. (1997) Molecular and cytogenetic analyses of stably and unstably expressed transgene loci in tobacco. Plant Cell, 9, 1251-1264.

Jahier, J., \& Tanguy, A. M. (1996). Observation of Chromosomes: Basic Techniques (Mitosis) of Plants Cytogenetics. Science Publishers Inc. New Hampshire. USA.

Kim, W. S., Ohashi, M., Tanaka, T., Kumura, H., Kim, G. Y., Kwon, I. K., ... Shimazaki, K. (2004) Growth-promoting effects of lactoferrin on L. acidophilus and Bifidobacterium ssp. Biometals, 17, 279-283. http://dx.doi.org/10.1023/B:BIOM.0000027705.57430.f1

Kurata, N., \& Omura, T. (1978). Karyotype analysis in rice. I. A new method for identifying all chromosomes pairs. Japan. J. Genetics, 53(4), 251-255.

Kurata, N., Omura, T., \& Iwata, N. (1981). Studies on centromere, chromomere and nucleolus in pachytene nuclei of rice, Oryza sativa L., microsporocytes. Cytologia, 46, 791-800. http://dx.doi.org/10.1266/jjg.53.251

Laemmli, U. K. (1970). Cleavage of structural proteins during the assembly of the head of bacteriophage T4. Nature, 227, 680-685. http://dx.doi.org/10.1508/cytologia.46.791

Levan, A., Fredga, K., \& Sanberg, A. A. (1964). Nomenclature for centromeric position on chromosomes. Hereditas, 52, 201-220. http://dx.doi.org/10.1111/j.1601-5223.1964.tb01953.x

Lönnerdal, B. (2000). Clinical studies on lactoferrin added to infant formula. In K. Shimazaki et al. (Eds.), Proceedings of the 4th International Conference on Lactoferrin: Structure, Function and Applications (pp. 291-300). Elsevier Science B.V. The Netherlands.

Ma, J. K. C., Drake, P. M. W., \& Christou, P. (2003). The production of recombinant pharmaceutical proteins in plants. Nature Rev. Genetics, 4, 794-805. http://dx.doi.org/10.1038/nrg1177

Mudjisihono, R., Santosa, T., \& Hendrata, R. (2002). Report of assessment on Rojolele rice variety in Klaten. Research Agency for Agriculture Technology, Yogyakarta, Indonesia.

Murray, M. G., \& Thompson, W. F. (1980). Rapid isolation of high molecular weight plant DNA. Nucleic Acid Research, 8(19), 4321-4326. http://dx.doi.org/10.1093/nar/8.19.4321

Nandi, S., Suzuki, Y. A., Huang, J., Yalda, D., Pham, P., Wu, L., ... Lönnerdal, B. (2002). Expression of human lactoferrin in transgenic rice grains for the application in infant formula. Plant Sci., 163, 713-722. http://dx.doi.org/10.1016/S0168-9452(02)00165-6

Palacpac, N. Q., Yoshida, S., Sakai, H., Kimura, Y., Fujiyama, K., Yoshida, T., \& Seki, T. (1999). Stable expression of human $\beta 1,4$-galactosyltransferase in plant cells modifies $\mathrm{N}$-linked glycosylation patterns. Proc. Natl. Acad. Sci. USA, 96, 4692-4697. http://dx.doi.org/10.1073/pnas.96.8.4692

Rachmawati, D., Mori, T., Hosaka, T., Takaiwa, F., Inoue, E., \& Anzai, H. (2005). Production and Characterization of Recombinant Human Lactoferrin in Transgenic Javanica Rice. Breeding Science, 55, 213-222. http://dx.doi.org/10.1270/jsbbs.55.213

Rayon, C., Lerouge, P., \& Paye, L. (1998). The protein N-glycosylation in plants. J. Exp. Bot., 49, 1463-1472.

Singh, G. (1999). Plant Systematics (pp. 176-180). Science Publishers, Inc. USA.

Spik, G., \& Theisen, M. (2000). Characterization of the post-translational biochemical processing of human lactoferrin expressed in transgenic tobacco. Bundesgesundheitsbl-Gesundheitsforch-Gesundheitsschutz, 43, 104-109. http://dx.doi.org/10.1007/s001030050019

Tomita, M., Wakabayashi, H., Teraguchi, S., \& Hayasawa, H. (2000). Importance of pathogen-eliminating systems in host protection by lactoferrin feeding. In K. Shimazaki et al. (Eds), Proceedings of the 4th International Conference on Lactoferrin: Structure, Function and Applications (pp. 175-180). The Netherlands: Elsevier Science B.V.

Twyman, R. M., Stöger, E., Schillberg, S., Christou, P., \& Fischer, R. (2003). Molecular farming in plants: host system and expression technology. TRENDS in Biotech, 21, 570-578. http://dx.doi.org/10.1016/j.tibtech.2003.10.002

Werner, S., Breus, O., Symonenko, Y., Marillonnet, S., \& Gleba, Y. (2011). High-level recombinant protein expression in transgenic plants by using a double-inducible viral vector. PNAS, 108(34), 14061-14066. http://dx.doi.org/10.1073/pnas.1102928108 
Xu-Gang, L., Song-Biao, C., Zi-Xian, L., Tuan-Jie, C., Qian-Chun, Z., \& Zhen, Z. (2002). Impact of copy number on transgene expression in tobacco. Acta Bot Sin, 44, 120-123.

\section{Copyrights}

Copyright for this article is retained by the author(s), with first publication rights granted to the journal.

This is an open-access article distributed under the terms and conditions of the Creative Commons Attribution license (http://creativecommons.org/licenses/by/3.0/). 